\title{
Molecular characterization of bovine placental and ovarian $20 \alpha$-hydroxysteroid dehydrogenase
}

\author{
Purevjargal Naidansuren, Cha-Won Park, Sang-Hwan Kim, Tseeleema Nanjidsuren, Jong-Ju Park, \\ Seong-Jo Yun, Bo-Woong Sim, Seongsoo Hwang ${ }^{1}$, Myung-Hwa Kang ${ }^{2}$, Buom-Yong Ryu ${ }^{3}$, \\ Sue-Yun Hwang ${ }^{1}$, Jong-Taek Yoon ${ }^{1}$, Keitaro Yamanouchi ${ }^{4}$ and Kwan-Sik Min
}

Animal Biotechnology, Graduate School of Bio and Information Technology, Institute of Genetic Engineering, Hankyong National University, Ansung 456-749, Republic of Korea, ${ }^{1}$ National Institute of Animal Science, Suwon 441-706, Republic of Korea, ${ }^{2}$ Department of Food and Nutrition, Hoseo University, Asan 336-795, Republic of Korea, ${ }^{3}$ Department of Animal Science and Technology, Chung-Ang University, Ansung 456-756, Republic of Korea and

${ }^{4}$ Department of Veterinary Physiology, Veterinary Medical Science, The University of Tokyo, Tokyo 113-8657, Japan

Correspondence should be addressed to K-S Min; Email: ksmin@hknu.ac.kr

\begin{abstract}
The enzyme $20 \alpha$-hydroxysteroid dehydrogenase (20 $\alpha$-HSD) catalyzes the conversion of progesterone to its inactive form, $20 \alpha-$ hydroxyprogesterone. This enzyme plays a critical role in the regulation of luteal function in female mammals. In this study, we conducted the characterization and functional analyses of bovine $20 \alpha-\mathrm{HSD}$ from placental and ovarian tissues. The nucleotide sequence of bovine $20 \alpha$-HSD showed significant homology to that of goats $(96 \%)$, humans $(84 \%)$, rabbits $(83 \%)$, and mice $(81 \%)$. The $\mathrm{mRNA}$ levels increased gradually throughout the estrous cycle, the highest being in the corpus luteum (CL) 1 stage. Northern blot analysis revealed a $1.2 \mathrm{~kb}$ mRNA in the bovine placental and ovarian tissues. An antibody specific to bovine $20 \alpha$-HSD was generated in a rabbit immunized with the purified, recombinant protein. Recombinant $20 \alpha-H S D$ protein produced in mammalian cells had a molecular weight of $\sim 37 \mathrm{kDa}$. Bacterially expressed bovine 20 $\alpha$-HSD protein showed enzymatic activity. The expression pattern of the 20 $\alpha$-HSD protein in the pre-parturition placenta and the CL1 stage of the estrous cycle was similar to the level of 20 $\alpha$-HSD mRNA expression. Immunohistochemical analysis also revealed that bovine $20 \alpha-H S D$ protein was intensively localized in the large luteal cells during the late estrous cycle.

Reproduction (2011) 142 723-731
\end{abstract}

\section{Introduction}

In all mammalian species, progesterone is essential in the preparation for and maintenance of pregnancy, if it occurs. Progesterone primes the endometrium for possible implantation and inhibits uterine contraction until birth. Aldo-keto reductases (AKRs) belong to a superfamily of NADPH-dependent reductases that act on a wide range of substrates, including simple carbohydrates, steroid hormones, and endogenous prostaglandins (Jez et al. 1997). The 20 $\alpha$-hydroxysteroid dehydrogenase $(20 \alpha-\mathrm{HSD})$ is a member of AKR family (Liu et al. 2007).

The $20 \alpha-H S D$ enzyme predominantly converts progesterone into its biologically inactive form, 20 $\alpha$ hydroxyprogesterone (20 $\alpha$-OHP) and plays a crucial role in the termination of pregnancy and the initiation of parturition (Seong et al. 2002). Accordingly, 20 $\alpha$-HSD in the placenta may be involved in reducing the cytotoxic effects of progesterone in the developing fetus. The biological functions of $20 \alpha$-HSD have been intensively studied in rats and mice because the enzyme plays a pivotal role in rodent reproduction (Albarracin et al. 1994, Dufort et al. 1996, Akinola et al. 1997, Bryndova et al. 2006).

The potential role of $20 \alpha$-HSD in the corpus luteum $(\mathrm{CL})$ during pregnancy has been determined by cloning the mouse 20 $\alpha$-HSD cDNA (Ishida et al. 1999). 20 $\alpha$ HSD is expressed in the CL of rats and mice and has been shown to be involved in the process of functional luteolysis during the rodent estrous cycle (Miura et al. 1994, Seong et al. 2002). In rodents, 20 $\alpha$-HSD activity is suppressed in the $\mathrm{CL}$ by prolactin or placental lactogens during pregnancy and abruptly increases before parturition, which is associated with a decrease in progesterone levels and a reciprocal increase in $20 \alpha$-OHP levels (Akinola et al. 1997). Notably, 20 $\alpha$-HSD has also been found in the placenta of rats (Shiota et al. 1993), mice 
(Ishida et al. 1999), goats (Jayasekara et al. 2004), and humans (Stickler et al. 1981, Zhang et al. 2000, Nakajima et al. 2003).

cDNA clones encoding bovine testicular 20 $\alpha$-HSD have been isolated from a bovine testicular $\lambda$ gt 11 library using polyclonal antibodies against $20 \alpha-\mathrm{HSD}$ and DNA probe hybridization (Warren et al. 1993). However, the nucleotide and deduced amino acid sequences of bovine $20 \alpha$-HSD showed very low similarity to goat 20 $\alpha$-HSD (43\%; Jayasekara et al. 2004). Bovine testicular $20 \alpha$-HSD has weak activity and differs markedly from the ovarian enzyme with respect to the amino acid sequence.

In this study, we determined the sequence of the entire bovine $20 \alpha$-HSD cDNA, analyzed the sequence homology, and generated a specific antibody against bovine $20 \alpha$-HSD using the recombinant protein produced in the Escherichia coli (E. coli) system. We then conducted northern blot analysis, expressed the recombinant protein in Chinese hamster ovary $(\mathrm{CHO})$ cells, and performed western blot and immunohistochemical analyses.

\section{Results}

\section{Determination of the bovine 20 $\alpha-H S D$ cDNA sequence}

Using partial cDNA cloning, a 572 bp fragment was amplified from bovine complete placentome tissue before parturition. Subsequently, two fragments of 350 and 300 bp were obtained using $3^{\prime}$ - and $5^{\prime}$-RACE respectively. The full nucleotide sequence of the cloned bovine $20 \alpha-H S D$ cDNA was 1127 bp, including 32 bp in the $5^{\prime}$-UTR, $123 \mathrm{bp}$ in the $3^{\prime}$-UTR, and $969 \mathrm{bp}$ in the open reading frame that encodes a putative protein of 323 amino acids (data not shown; GenBank accession number GU064907). Figure 1A shows the comparison of the deduced amino acid sequence of bovine $20 \alpha-\mathrm{HSD}$ with that of other species. According to a homology search, the nucleotide sequence of bovine 20 $\alpha$-HSD cDNA showed high homology to other animals (goat $96 \%$, human $84 \%$, rabbit $83 \%$, rat $81 \%$, and mouse $81 \%)$. However, the sequence showed very low homology to bovine testicular 20 $\alpha$-HSD cDNA (49\%) reported previously (Warren et al. 1993). The bovine testicular 20 $\alpha$-HSD cDNA encodes a protein of 307 amino acids that is identical to the cDNA of the bovine lens aldose reductase enzyme. Phylogenetic tree analysis of the $20 \alpha-\mathrm{HSD}$ amino acid sequence across various vertebrate species showed that bovine $20 \alpha$-HSD clusters with high bootstrap in the lineage of goats and humans, sharing the highest homology with goat $20 \alpha-$ HSD (Fig. 1B).

\section{Expression of bovine 20 $\alpha-H S D$ mRNA}

Using specific primers for $20 \alpha-H S D$ and amplification by reverse transcriptase-PCR (RT-PCR), we determined the expression levels of $20 \alpha-\mathrm{HSD}$ mRNA in the ovaries obtained from the $\mathrm{CL}$ during estrous cycle, the
A

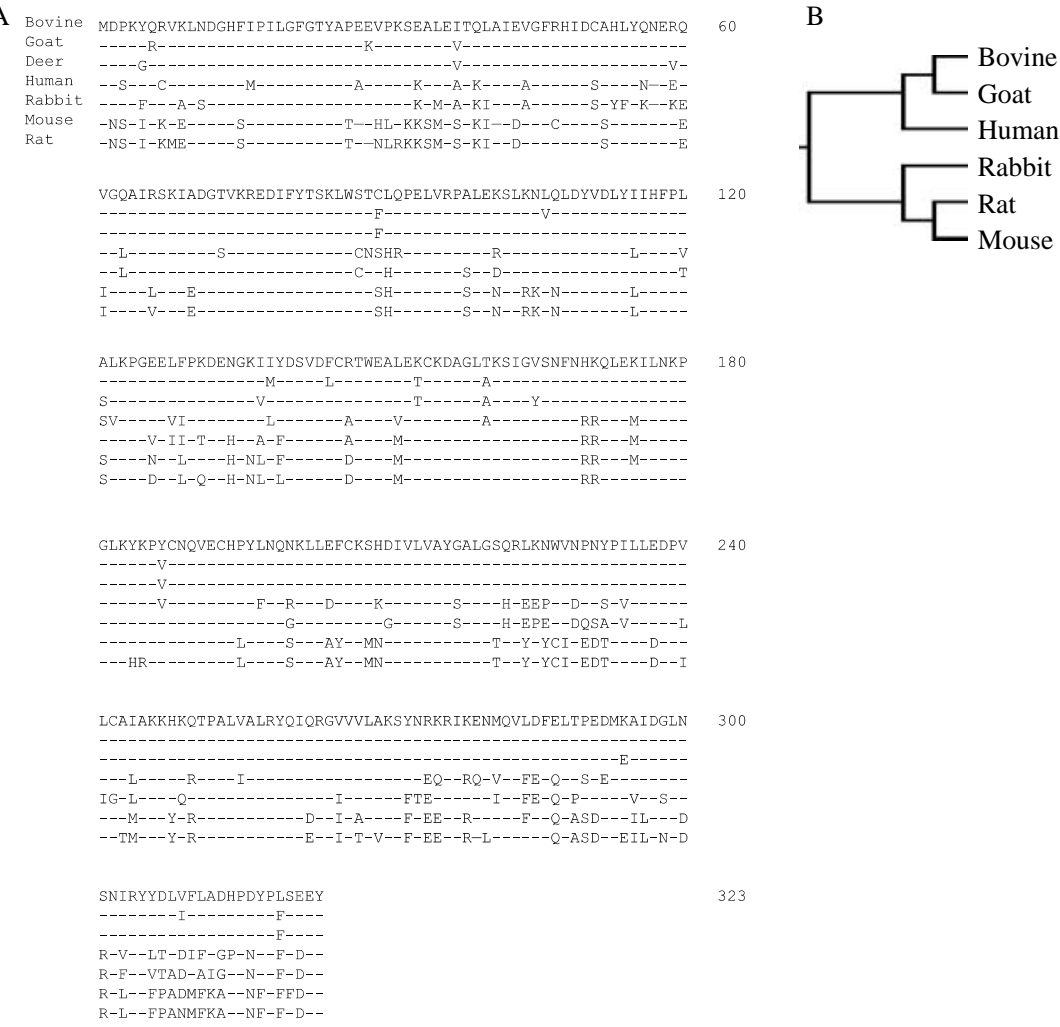

Figure 1 Comparison of the bovine $20 \alpha-\mathrm{HSD}$ and related sequences. (A) The deduced bovine $20 \alpha-$ HSD amino acid sequence was aligned with the amino acid sequence of goat, deer, rabbit, human, mouse, and rat 20 $\alpha$-HSD. Amino acids are presented in the conventional single-letter code and are numbered on the right. The $1 \mathrm{~F}$ and $3 \mathrm{R}$ PCR primers are boxed. Amino acid residues that are completely conserved across the species are indicated by dashed lines. (B) The phylogenetic tree of the bovine $20 \alpha-\mathrm{HSD}$ amino acid sequence was compared with the $20 \alpha-$ HSD sequences from other vertebrate species. The other $20 \alpha-\mathrm{HSD}$ amino acid sequences were obtained from GenBank, and the phylogenetic tree was constructed using the unrooted analysis with PHYLYP and Tree View. 


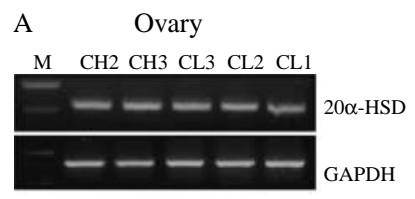

C Culture of luteal cells $\begin{array}{llllll}\text { M } & 0 & 24 & 72 & 96 & 120 \mathrm{~h}\end{array}$

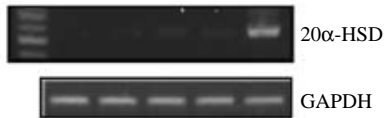

B Placenta

$=20 \alpha-\mathrm{HSD}$

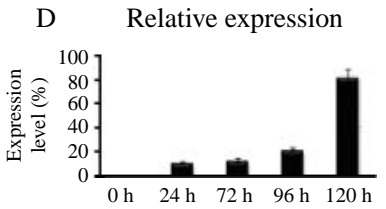

Figure 2 Expression of the bovine $20 \alpha$-HSD gene in the ovary throughout the estrous cycle, the pre-parturition placenta, and in cultured luteum cells. (A) We randomly collected ovaries at different times throughout the estrous cycle. The corpus luteum at the estrous cycle was divided according to CL stages. (B) Placentomes were obtained from cesarean delivery on day 283 of gestation from Korean native bovines. (C) Bovine 20 $\alpha$-HSD mRNA was detected in cultured corpus luteum cells. The corpus luteum cells of the $\mathrm{CH} 2$ stage were cultured until $120 \mathrm{~h}$. (D) The relative expression of the $20 \alpha-H S D$ gene (mean \pm s.D.) present in three sets of samples evaluated by PCR. Total RNA was extracted and analyzed by RT-PCR. The PCR products were then separated by agarose gel electrophoresis. Representative PCR results are shown. The amplified products of $20 \alpha-\mathrm{HSD}$ and GAPDH were separated by electrophoresis and stained with ethidium bromide. $\mathrm{M}$, DNA size marker; $\mathrm{CH}$, corpus hemarrhagicum; $\mathrm{CL}$, corpus luteum.

placentome on day 283 of pregnancy, and cultured luteal cells; $20 \alpha-H S D$ was expressed in all ovarian and placentome tissue (Fig. 2A and B). Next, we determined the mRNA expression level in cultured bovine CL cells during the corpus hemarrhagicum $(\mathrm{CH}) 2$ stage. As shown in Fig. 2C, 20 $\alpha$-HSD mRNA expression was first found at $24 \mathrm{~h}$ after culture, and increased $120 \mathrm{~h}$ after culture. For northern blot analysis, total RNA was extracted from the $\mathrm{CL}(\mathrm{CH} 2, \mathrm{CH} 3, \mathrm{CL} 3, \mathrm{CL} 2$, and CL1) during the estrous cycle and from the placentome at preparturition. A strong 20 $\alpha$-HSD mRNA band with a size of $\sim 1.2 \mathrm{~kb}$ was observed. 20 $\alpha$-HSD mRNA was not detected in the $\mathrm{CL}$ of the $\mathrm{CH} 2, \mathrm{CH} 3$, and $\mathrm{CL} 3$ stages, but was strongly detected in the CL2 and CL1 stages (Fig. 3). This pattern was very similar to the RT-PCR result. The $20 \alpha-H S D$ mRNA expression was also strongly detected in the pre-parturition placenta.

\section{Production of a 20 $\alpha-H S D$ polyclonal antibody}

Bovine $20 \alpha$-HSD protein was expressed in the E. coli system using the pRSET expression plasmid vector, and the protein was purified by diethylaminoethanol (DEAE) column chromatography. Bovine $20 \alpha-\mathrm{HSD}$ protein was detected at the predicted molecular weight of $37 \mathrm{kDa}$ by SDS-PAGE and Coomassie blue staining (Fig. 4A). The recombinant protein was injected three times into two rabbits, and blood was collected after the final injection. One of the rabbits responded to the recombinant protein, and its serum was purified to produce a specific antibody against bovine $20 \alpha-\mathrm{HSD}$ by chromatography.

\section{Expression of recombinant 20 $\alpha-H S D$ in the CHO-K1 cell line}

Two expression vectors (pcDNA3 + b20 $\alpha$-HSD and pcDNA4/HisMax + b20 $\alpha-H S D)$ were transiently transfected into $\mathrm{CHO}-\mathrm{K} 1$ cells, after which the cell lysates were collected and subjected to SDS-PAGE. The specific antibody for $20 \alpha$-HSD produced in this study was used to detect the level of the recombinant protein produced by the two expression vectors via western blot analysis. The blots for pcDNA3+b20 $\alpha$-HSD and pcDNA4/HisMax + b20 $\alpha-H S D$ showed single protein bands with molecular weights of 37 and $41 \mathrm{kDa}$ respectively (Fig. 4B); the size difference was attributed to a $4 \mathrm{kDa}$ tag on the protein expressed by the pcDNA4/HisMax vector.

\section{Western blot analysis in the placenta and CL tissues}

As shown in Fig. 5A, a $37 \mathrm{kDa}$ band corresponding to bovine $20 \alpha$-HSD protein was detected. A strong signal was detected in the ovaries of the CL3, CL2, and CL1 stages, but no signal was detected in the ovaries of the $\mathrm{CH} 2$ and $\mathrm{CH} 3$ stages. The $20 \alpha-\mathrm{HSD}$ protein level was the highest in the $\mathrm{CL}$ undergoing luteolysis throughout the estrous cycle. Comparison of the level of $20 \alpha-\mathrm{HSD}$ protein with that of mRNA in the ovaries during the estrous cycle showed a similar pattern. The protein expression level was also assessed in the normal placenta (Fig. 5B) and was robustly expressed on the cotyledon side of the placenta before parturition.

\section{Analysis of 20 $\alpha-H S D$ enzymatic activity of the purified protein}

The enzymatic activity of bacterially expressed protein is shown in Fig. 6. One unit of enzymatic activity was defined as the amount of enzyme that catalyzed the formation of $1 \mathrm{nmol} \mathrm{NADPH} / \mathrm{min}$. Purified 20 $\alpha$-HSD protein showed enzymatic activity in a dose-dependent manner $(0-25 \mu \mathrm{g})$.

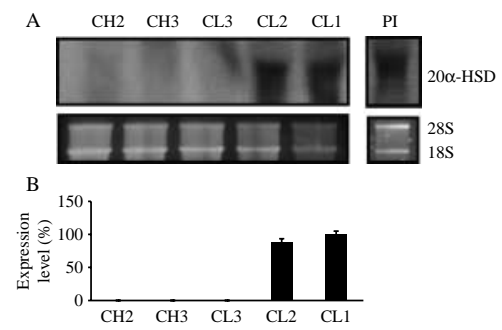

Figure 3 Northern blot analysis of bovine $20 \boldsymbol{\alpha}$-HSD mRNA expression throughout the estrous cycle in the ovaries and pre-parturition placenta. (A) Northern blot analysis with $10 \mu \mathrm{g}$ total RNA/lane. (B) The relative expression of $20 \alpha-H S D$ is presented. The blots shown are the results of a representative experiment. $\mathrm{CH}$, corpus hemarrhagicum; $\mathrm{CL}$, corpus luteum; Pl, placenta. 185 rRNA was used as a loading control. 


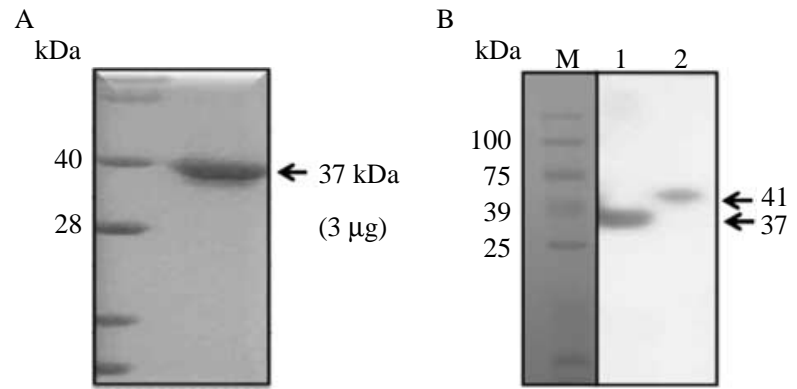

Figure 4 Expression of bovine $20 \alpha-\mathrm{HSD}$ protein in E. coli and $\mathrm{CHO}$ cell lines. (A) SDS-PAGE of purified recombinant 20 $\alpha$-HSD. E. coli transfected with pRSET + b20 $\alpha$-HSD was cultured, and the purified recombinant bovine $20 \alpha-\mathrm{HSD}$ protein was separated by SDS-PAGE. (B) Bovine $20 \alpha-\mathrm{HSD}$ recombinant protein produced in $\mathrm{CHO}-\mathrm{K} 1$ cells was analyzed by immunoblot. The bands corresponding to the protein produced by pcDNA3 + b20 $\alpha-\mathrm{HSD}$ and pcDNA4/HisMax $+\mathrm{b} 20 \alpha-\mathrm{HSD}$ vectors were detected. After gel electrophoresis, the proteins were transferred to a nitrocellulose membrane, and the protein was detected with bovine $20 \alpha-\mathrm{HSD}$ antiserum followed by staining with goat anti-rabbit IgG-POD. Lane 1, pcDNA3 + b20 $\alpha$-HSD; lane 2, pcDNA4/HisMax +b20 $\alpha$-HSD.

\section{Immunolocalization of $20 \alpha-H S D$ in the ovary during the estrous cycle}

To determine the cell types that are responsible for $20 \alpha$-HSD protein expression in the ovary, we performed immunohistochemical analysis on luteal cells of the ovaries during the estrous cycle. As shown in Fig. 7, $20 \alpha$-HSD was strongly localized in the large luteal cells and was; especially intense in the $\mathrm{CL}$ of the ovaries at the terminal stage of the estrous cycle. Notably, Fig. 7 shows that $20 \alpha$-HSD was mainly expressed in the large luteal cells. We also determined the localization of $20 \alpha-\mathrm{HSD}$ in cultured bovine and rat luteal cells. The data shown in Fig. 8 indicate that this protein is expressed in both bovine and rat cultured corpus luteal cells. 20 $\alpha$-HSD was mainly localized around the nucleus in the cultured CL cells.

\section{Discussion}

This is the first report describing $20 \alpha-\mathrm{HSD}$ expression in the ovarian and placental tissues of a bovine species. It was expected that the expression and localization studies would reveal a stage-specific expression pattern in bovine ovaries. Although bovine testicular 20 $\alpha$-HSD was cloned, the sequence showed very low homology to that of other animals. Bovine testicular 20 $\alpha$-HSD has weak $20 \alpha-H S D$ activity, and it markedly differs from the ovarian enzyme with respect to its amino acid sequence (Warren et al. 1993). Bovine testicular 20 $\alpha$-HSD encoded a protein of only 307 amino acids, and the nucleotide sequence was identical to the bovine lens aldose reductase enzyme. Based on the expression pattern and activity, these results suggest that gene cloned in this study is bovine $20 \alpha-\mathrm{HSD}$ cDNA.
Phylogenetic analysis revealed that bovine $20 \alpha-\mathrm{HSD}$ was evolutionarily closer to the cloned goat $20 \alpha-\mathrm{HSD}$ sequence but more distantly related to the rat and mouse sequences. Although the amino acid sequence of bovine $20 \alpha$-HSD shares about $66-68 \%$ identity with other mammals, the specific regions of the AKR family are conserved across various species (Jez et al. 1997, Jayasekara et al. 2004). Several conserved sequence patterns were found in the bovine $20 \alpha-\mathrm{HSD}$ cloned in this study. The catalytic tetrad such as Asp 50, Tyr 55, Lys 84, and His 117 is a common feature of the AKR family (Penning 1997). Other amino acids such as Gly 22, Gly 45, Asp 112, Pro 119, Gly 164, Asn 167, Pro 186, Gln 190, and Ser 271 are strictly conserved in the primary structure of all the members of the AKR family (Jez et al. 1997). Thus, these amino acids may play a role in conferring the appropriate tertiary structure necessary for functional activity.

The mRNA expression analysis shows that the enzyme is strikingly lower in the ovaries of the $\mathrm{CH} 2$ and $\mathrm{CH} 3$ stages; however, levels were remarkably higher in the $\mathrm{CL}$ of the late estrous cycle and placenta before parturition, thus suggesting its important role in the production of ovarian $20 \alpha-$ HSD during the late estrous cycle and in the placenta during pregnancy. Goat $20 \alpha-H S D$ was expressed in the placenta and intercaruncular part of the uterus during mid-to-late pregnancy but not in the adrenal gland, liver, or spleen during pregnancy (Jayasekara et al. 2004, 2005). Human $20 \alpha-H S D$ is highly expressed in the liver, mammary gland, and brain, whereas its expression is lower in the prostate, testis, and uterus and is remarkably low in the adrenal gland (Zhang et al. 2000). However, in our study, we did not detect $20 \alpha$-HSD expression in other tissues, except the placenta, ovary, and cultured luteal cells. The expression of $20 \alpha$-HSD in cultured bovine CL cells was consistent with its expression in rat cells; i.e. the amount of $20 \alpha-H S D$ mRNA increased spontaneously in a time-dependent manner (Hirabayashi et al. 2004).

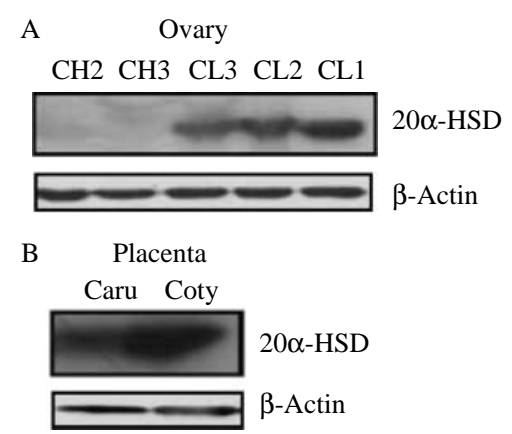

Figure 5 Western blot analysis of the bovine ovary during the estrous cycle and pre-parturition placenta. (A) Corpus luteum tissues throughout the estrous cycle $(\mathrm{CH} 2, \mathrm{CH} 3, \mathrm{CL} 3, \mathrm{CL} 2$, and CL1). (B) The placentome was collected on day 283 of pregnancy. Placentas were divided into the caruncle and cotyledon. $\beta$-Actin was used as the loading control; Caru, Caruncle; Coty, Cotyledon. 


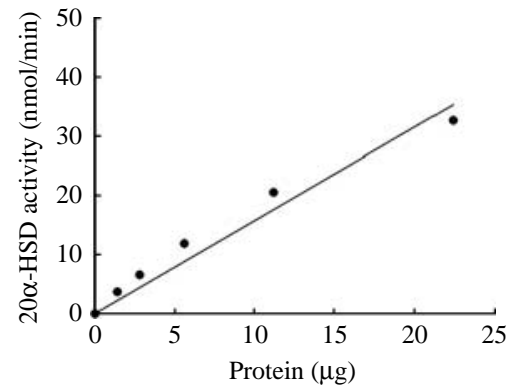

Figure 6 Catalytic activity of bacterially expressed purified 20 $\alpha$-HSD protein. The enzyme activity was measured by spectrophotometry. Each point represents the mean values of three separate experiments.

Northern blot analysis revealed that bovine 20 $\alpha$-HSD mRNA was markedly expressed in the placenta at the end of pregnancy. Moreover, these results may provide insight into the role of the $20 \alpha$-HSD gene at the above mentioned phases of pregnancy. Our data were closely consistent with the results from previous studies that indicated that $20 \alpha-\mathrm{HSD}$ mRNA was highly expressed at the end of pregnancy and during the late estrous phase (Albarracin et al. 1994, Jayasekara et al. 2004).

Bovine AKR1B5/PGFS, which mediates 20 $\alpha$-HSD activity, was highly expressed during the estrous cycle and in endometrial cell cultures at times immediately preceding the expected production of $\mathrm{PGF}_{2 \alpha}$ (Madore et al. 2003). 20 $\alpha$-HSD/PGFS (AKR1B5) was widely expressed in uninucleated trophoblast cells of chorionic villi in a more constitutive manner (Schuler et al. 2006). AKR1B5 expression peaks around day 12, with progesterone simultaneously reaching its highest systemic concentration. Its expression is different from the bovine $20 \alpha$-HSD gene, which is highly expressed during the late estrous cycle in this study. To verify the enzymatic activity of the recombinant $20 \alpha-\mathrm{HSD}$ that was produced and purified in a bacterial system, we analyzed the rate of conversion of NADP to NADPH in the presence of $20 \alpha$-OHP. $20 \alpha$-HSD activity was recorded at $\sim 1.6 \mathrm{nmol} / \mathrm{min}$ per $\mu \mathrm{g}$ protein and showed enzymatic activity similar to other species (Jayasekara et al. 2004), thus confirming that the isolated cDNA was indeed bovine $20 \alpha-H S D$ cDNA. Although AKR1B5 has inactivated progesterone, the gene has weak $20 \alpha$-HSD activity and a different number of amino acids (Warren et al. 1993). We cautiously suggest that the $20 \alpha-H S D / P G F S$ (AKR1B5) may not be the genuine 20 $\alpha$-HSD gene and hold that the gene cloned in this study is the actual bovine $20 \alpha$-HSD gene as demonstrated by our results regarding expression and activity.

$20 \alpha$-HSD protein expression was only detected in the ovaries of the CL3, CL2, and CL1 stages throughout the estrous cycle; it was also robustly expressed in the cotyledon side of the placenta just before parturition. $20 \alpha-\mathrm{HSD}$ expression increased according to the phase of the estrous cycle, and mostly mirrored the mRNA expression pattern. This observation is consistent with previous reports showing the presence of $20 \alpha-\mathrm{HSD}$ mRNA (Stickler et al. 1981, Ishida et al. 1999, Nakajima et al. 2003, Jayasekara et al. 2004) and protein (Shiota et al. 1993, Seong et al. 2002) in the placenta. However, both rat $20 \alpha$-HSD protein and mRNA were undetectable until just before parturition, during which the enzyme was abundantly expressed (Albarracin et al. 1994). The bovine placenta was shown to express considerable $20 \alpha-H S D$, as in goat (Jayasekara et al. 2004) and deer placental tissues (P Naidansuren, CW Park, T Nanjidsuren, JJ Park, SJ Yun, BW Sim, MH Kang \& KS Min, unpublished data). Bovine $20 \alpha-H S D$ protein was intensely localized to large luteal cells at the late estrous cycle. This is the first study to investigate the localization of bovine $20 \alpha$-HSD protein in the ovary during the estrous cycle. In rats, immunoreactivity of the $20 \alpha-H S D$ protein was revealed in decidual cells and trophoblastic giant cells on day 10 and spongiotrophoblasts and visceral yolk sac cells on day 21 of pregnancy (Shiota et al. 1993). We also determined that the expression of $20 \alpha-H S D$ was mainly localized around the nucleus in cultured CL cells. The abrupt expression of $20 \alpha-H S D$ at the end of pregnancy may be partly due to the expression of $\mathrm{PGF}_{2 \alpha,}$ the level of which increases at the end of pregnancy. $\mathrm{PGF}_{2 \alpha}$ markedly stimulates the activity of $20 \alpha-H S D$, and the molecular mechanism underlying this stimulation has not yet been elucidated (Stocco et al. 2000, 2002). Bovine 20 $\alpha$-HSD mRNA and protein were markedly expressed in the late estrous cycle, which is consistent with the view that functional luteolysis is associated with an increase in $20 \alpha$-HSD activity. In addition to ovary, the expression of bovine $20 \alpha-\mathrm{HSD}$ in the placenta
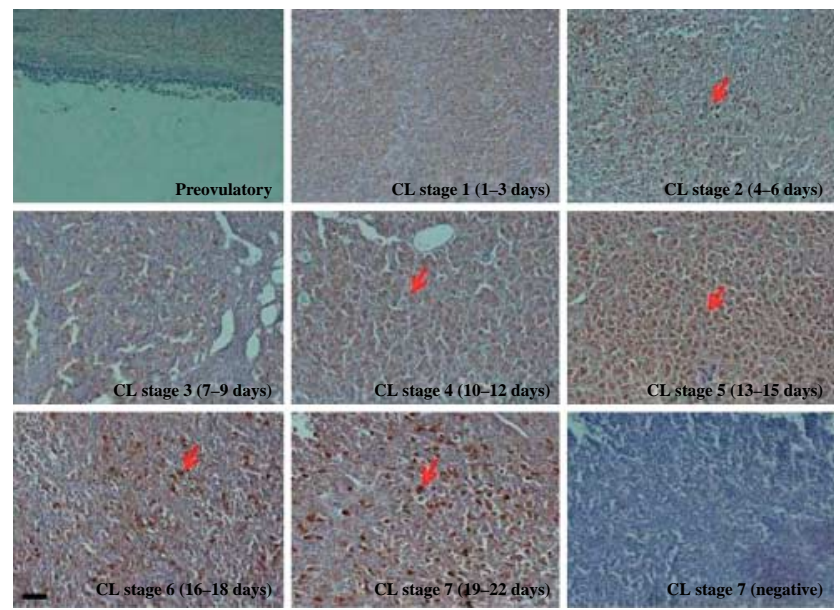

Figure 7 Localization of bovine $20 \alpha-\mathrm{HSD}$ protein expression in the $\mathrm{CL}$ throughout the estrous cycle by immunohistochemistry. Representative immunohistochemical analyses using 20 $\alpha$-HSD antiserum (1:1000) and goat anti-rabbit secondary antibodies (1:500). Preimmune serum (1:1000) was used for primary antiserum as the negative control. Immunohistochemistry was performed by a Vectastain ABC kit. Ovarian sections are shown during the estrous cycle. Preimmune serum was used as the control for the CL stage 7 below the right panel. Black bar $=100 \mu \mathrm{m}$. Red arrows indicate luteal cells. 

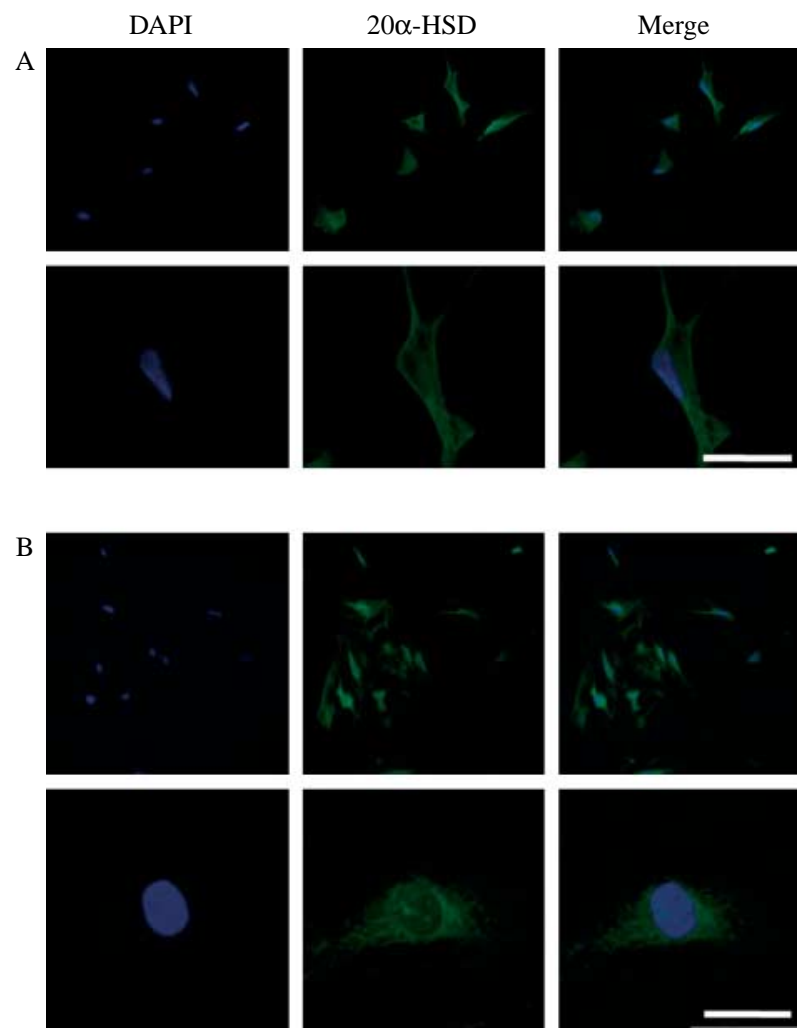

Figure 8 Bovine $20 \alpha$-HSD expression in cultured bovine and rat corpus luteum cells by immunofluorescence. Counter staining was performed with DAPI (blue). Bovine $20 \alpha$-HSD expression was detected by Alexa 488 (green). The merged picture shows blue and green colors. (A) Bovine luteal cells. (B) Rat corpus luteal cells. White bars $=100 \mu \mathrm{m}$.

may greatly contribute to the progression of pregnancy by controlling peripheral progesterone concentrations.

In summary, we identified the nucleotide sequence and expression pattern of the $37 \mathrm{kDa}$ protein located specifically in the luteal cells and characterized the protein as $20 \alpha-H S D$, a member of the AKR family of enzymes. Our study also demonstrated that $20 \alpha-\mathrm{HSD}$ mRNA and protein are coordinately expressed in the $\mathrm{CL}$ throughout the estrous cycle. Thus, the bovine $20 \alpha-\mathrm{HSD}$ gene might control important mechanisms during the estrous cycle. The fact that recombinant $20 \alpha$-HSD can be expressed and readily purified using bacterial and mammalian expression systems indicates that these are excellent choices for exploring the detailed mechanism of action of multifunctional enzymes. 20 $\alpha-\mathrm{HSD}$ mRNA and protein were highly upregulated in the cotyledon of the placenta at the end of pregnancy. Further studies are needed to determine the functional significance of bovine $20 \alpha-H S D$ during pregnancy and parturition.

\section{Materials and Methods}

\section{Materials}

The cloning vector pCR2.1, expression vectors pcDNA3 and pcDNA4/HisMax, GeneRacer Kit, and the Super Script
First-Strand Synthesis System were purchased from Invitrogen Life Technologies. Restriction enzymes and the DNA ligation kit were purchased from Takara (Tokyo, Japan). The One-step SYBR RT-PCR kit was purchased from ToYoBo (Osaka, Japan). PRO-PREP protein extraction solution was purchased from Intron Biotechnology (Seoul, Korea). The digoxigenin (DIG) DNA labeling kit and the Lumi-Light western blot kit were bought from Roche. Horse serum, goat serum, the avidinbiotin-HRP (ABC) detection kit, 3,3'-diaminobenzidine (DAB), hematoxylin and methyl green were purchased from Vector Laboratories (Burlingame, CA, USA). Anti-rabbit immunoglobulins and Alexa 488 secondary antibody were purchased from Dako Cytomation (Glostrup, Denmark). E. coli competent cells were from Yeastern Biotech Co. Ltd. (Seoul, Korea). Serum-free CHO-S-SFM II and Lipofectamine 2000 reagents were purchased from Gibco BRL. Fetal bovine serum (FBS) was obtained from Hyclone Laboratories (Logan, UT, USA). The oligonucleotides were synthesized by Genotech (Daejeon, Korea), and all other chemicals were obtained from local suppliers.

\section{Tissues}

Placental tissues were obtained from cesarean delivery on day 283 of gestation. The placentas were collected and stored at $-80^{\circ} \mathrm{C}$ until use. $\mathrm{CL}$ tissues were classified into five groups according to the stage of estrous cycle that was based on the ovarian morphology as follows: days 4-6 (CH2), 7-12 (CH3), 13-15 (CL3), 16-18 (CL2), and 19-21 (CL1). CH (CH2 and $\mathrm{CH} 3)$ and $\mathrm{CL}(\mathrm{CL} 3, \mathrm{CL} 2$ and $\mathrm{CL} 1)$ samples were divided into the $\mathrm{CL}$ classes as previously reported (Arosh et al. 2002). All experiments were conducted according to the Guidelines for the Care and Use of Animals, Hankyong National University.

\section{Preparation of the bovine 20 $\alpha-H S D$ cDNA fragment}

The primers for PCR were designed according to the homologous part of the $20 \alpha-\mathrm{HSD}$ cDNA sequence as previously reported (Lacy et al. 1993, Mao et al. 1994, Ishida et al. 1999, Jayasekara et al. 2004). The specific primers (sense: 5'-GTG AAG AGA GAA GAC ATA TTC-3' and antisense: $5^{\prime}$-CCA CGT TGT ATC TGG TAG CGA AGG-3') were also synthesized from the nucleotide sequence of the cloned $20 \alpha$-HSD gene. Total RNA was extracted using the Trizol reagent (Invitrogen), and cDNA synthesis was performed by the SuperScript First-Strand Synthesis System according to the manufacturer's instructions. Next, PCR was carried out using 2.5 units of Pfu polymerase on Quick Thermo-II and consisted of 30 cycles of denaturation $\left(91^{\circ} \mathrm{C}\right.$ for $\left.1 \mathrm{~min}\right)$, annealing $\left(37^{\circ} \mathrm{C}\right.$ for $1 \mathrm{~min})$, and extension $\left(72^{\circ} \mathrm{C}\right.$ for $\left.2 \mathrm{~min}\right)$. The PCR products were analyzed by electrophoresis in Tris-acetate buffer containing EDTA. The PCR fragments (572 bp) were ligated into the pCR2.1 vector, and sequence data were analyzed using computer software (DNASIS).

\section{$3^{\prime}$ - and $5^{\prime}-R A C E$}

GeneRacer 3'-primer (5'-GCT GTC AAC GAT ACG CTA CGT AAC G-3') and GeneRacer $3^{\prime}$-nested primer (5'-CGC TAC GTA ACG GCA TGA CAG TG-3') for 3'-RACE were designed 
according to the nucleotide sequence of the resulting PCR product. The gene-specific primer GeneRacer 5'-primer (5'CGA CTG GAG CAC GAG GAC ACT GA-3') and GeneRacer 5'-nested primer (5'-GGA CAC TGA CAT GGA CTG AAG GAG TA-3') for $5^{\prime}$-RACE were designed according to the nucleotide sequence of the resulting PCR product. The $3^{\prime}$ - and $5^{\prime}$-RACE were performed by the GeneRacer Kit (Invitrogen) according to the manufacturer's instructions.

\section{RT-PCR and northern blotting analysis}

RT-PCR was performed by the AccuPower RT-PCR kit (RT/PCR PreMix). Total RNA (1.0 $\mu$ g) extracted from the bovine ovary, placenta, and $C L$ was mixed with the reverse primer (5'-GCC ATT GCC AAA AAG CAC AAG- $\left.3^{\prime}\right)$, incubated at $70^{\circ} \mathrm{C}$ for $5 \mathrm{~min}$, and then placed on ice. The forward primer $\left(5^{\prime}-\mathrm{GGA}\right.$ AAG CGG ATA GTC AGG GTG ATC- $3^{\prime}$ ) was then added, and the reaction volume $(20 \mu \mathrm{l})$ was attained with diethylpyrocarbonate-distilled water. The cDNA synthesis reaction was performed by the following protocol: $42{ }^{\circ} \mathrm{C}$ for $60 \mathrm{~min}$ and $94{ }^{\circ} \mathrm{C}$ for $5 \mathrm{~min}$. PCR was carried out according to the following protocol: $94{ }^{\circ} \mathrm{C}$ for $1 \mathrm{~min}$, followed by 30 cycles of $94{ }^{\circ} \mathrm{C}$ for $1 \mathrm{~min}, 56^{\circ} \mathrm{C}$ for $1.5 \mathrm{~min}$, and $72{ }^{\circ} \mathrm{C}$ for $1 \mathrm{~min}$. This was followed by a final extension at $72{ }^{\circ} \mathrm{C}$ for $8 \mathrm{~min}$. RNA electrophoresis was performed on an agarose gel containing $10 \times 3$-(4-morpholino) propane sulfonic acid and 37\% formaldehyde, and the total RNA concentration from bovine placenta and $\mathrm{CL}$ was diluted to $10 \mu \mathrm{g} / \mu \mathrm{l}$. After electrophoresis, the RNA was transferred onto a membrane with $20 \times$ salinesodium citrate and incubated overnight. The probe was prepared by purifying the sample after PCR amplification. Probe labeling was performed by the DIG DNA labeling kit. The membrane was pre-hybridized for $1 \mathrm{~h}$ at $68{ }^{\circ} \mathrm{C}$ and hybridized at $68{ }^{\circ} \mathrm{C}$ overnight with DIG-labeled bovine $20 \alpha$ HSD cDNA with gentle rocking. The bands were visualized the following day using an antibody conjugate and X-ray film for exposure.

\section{Production of polyclonal antibody}

The pRSET vector containing bovine 20 $\alpha$-HSD full-length CDNA was constructed and transformed into $E$. coli. Three colonies were selected to produce the recombinant protein. The protein was purified by DEAE column chromatography. Next, $5 \mu \mathrm{g}$ protein was coupled to $5 \mathrm{mg}$ maleimide-activated keyhole limpet hemocyanin according to the manufacturer's instructions. The conjugated protein was emulsified with an equal volume of Freund's complete adjuvant and s.c. injected into rabbits. One month after the initial injection, the rabbits were boosted with $\sim 200 \mu \mathrm{g}$ protein in an equal volume of incomplete Freund's adjuvant. Booster injections were then repeated at 2-week intervals. Total blood was collected and tested by western blot for recombinant bovine 20 $\alpha$-HSD prepared from $\mathrm{CHO}-\mathrm{K} 1$ cells. Only one rabbit injected with the recombinant protein developed antibodies against it. Finally, $\lg G$ fractions were prepared from the rabbit immune sera using protein-A chromatography.

\section{Construction of expression transfer vector and transient transfection into $\mathrm{CHO}$ cell lines}

Bovine $20 \alpha$-HSD genes cloned into the pCR2.1 vector were digested with Xhol and Xbal restriction enzymes. The digested fragments were ligated into eukaryotic expression vectors (pcDNA3 and pcDNA4/His Max) that had been digested with Xhol and Xbal. Each vector was completely sequenced to confirm the presence of the Kozak site and to rule out the possibility of any PCR errors. CHO-KI cell lines were cultured in growth medium (Ham's F12 media containing penicillin $(50 \mathrm{U} / \mathrm{ml})$, streptomycin $(50 \mathrm{mg} / \mathrm{ml})$, glutamine $(2 \mathrm{mM})$, and $10 \%$ FCS) and incubated at $37^{\circ} \mathrm{C}$ in $5 \% \mathrm{CO}_{2}$. Cultured $\mathrm{CHO}-$ $\mathrm{K} 1$ cells were transfected with the expression vectors by the liposome transfection method described previously (Min et al. 2004). After $4-6 \mathrm{~h}$ of transfection, $250 \mu \mathrm{l} 20 \%$ FBS was added to the wells, and the cells were maintained at $37^{\circ} \mathrm{C}$ in a $\mathrm{CO}_{2}$ incubator for $24 \mathrm{~h}$. On the following day, the transfected cells were washed twice, and then $500 \mu \mathrm{l}$ serum-free medium was added and the cells were incubated at $37^{\circ} \mathrm{C}$ for $48 \mathrm{~h}$. The culture media was then removed, and the cells were collected into a tube. The cells were centrifuged at $13000 \mathrm{~g}$ for $10 \mathrm{~min}$, and the cell debris was recovered.

\section{Measurement of 20 $\alpha-H S D$ enzymatic activity}

$20 \alpha$-HSD enzymatic activity of the purified protein was measured by spectrophotometry as previously reported (Jayasekara et al. 2004). Briefly, enzymatic activity was determined by the rate of conversion of NADP to NADPH in the presence of $20 \alpha$-OHP. The enzymatic reaction was initiated by adding various amounts of purified $20 \alpha$-HSD protein, and the absorbance was measured at $340 \mathrm{~nm}$. The enzymatic activity was defined as the amount of enzyme that catalyzed the formation of $1 \mathrm{nmol} \mathrm{NADPH} / \mathrm{min}$.

\section{Bovine and rat $C L$ cell culture}

Bovine $\mathrm{CL}$ cells were cultured from the ovary at the $\mathrm{CH} 2$ stage. First, the CL tissues were washed twice with $1 \times$ PBS and cut into $0.5 \mathrm{~cm}$ sections in DMEM. The tissues were then cultured with $0.2 \%$ collagenase at $37^{\circ} \mathrm{C}$ in a shaking incubator for $2 \mathrm{~h}$. The culture medium was filtered through a cell strainer and centrifuged at $1000 \mathrm{~g}$ for $5 \mathrm{~min}$, after which the supernatant was collected. Finally, cells were counted using a cytometer, and $2 \times 10^{6}$ cells were seeded onto a cell culture plate. Twenty six-day-old immature female Wistar rats housed in our laboratory were s.c. injected with $50 \mathrm{U}$ equine chorionic gonadotropin, and after $42 \mathrm{~h}$ they were i.p. injected with $10 \mathrm{U}$ human chorionic gonadotropin (hCG). After $6 \mathrm{~h}$, the rats were killed by decapitation, and the ovaries were isolated and collected in DMEM medium. The rat CL tissues were cultured in the same manner as the bovine CL cells.

\section{Western blot analysis}

Total proteins were extracted using the PRO-PREP protein extraction solution. Approximately $10-20 \mathrm{mg}$ ovarian and placental tissues were used. The tissues were minced and transferred to appropriate tubes. The samples were then 
homogenized in $600 \mu \mathrm{l}$ PRO-PREP solution, and cell lysis was induced by incubating the cells for $30 \mathrm{~min}$ on ice. Finally, the samples were centrifuged at $105000 \mathrm{~g}$ at $4{ }^{\circ} \mathrm{C}$ for $5 \mathrm{~min}$, and the supernatants were transferred to fresh $1.5 \mathrm{ml}$ tubes. The protein concentration was measured by the Bradford method (Bradford 1976). Samples were separated by SDS-PAGE and transferred to a PVDF membrane using a semidry electroblotter apparatus. After blotting, the membrane was blocked with a $1 \%$ blocking reagent for $1 \mathrm{~h}$ and incubated with a 1:1500 dilution of a polyclonal $20 \alpha-H S D$ antibody for $1 \mathrm{~h}$. The membrane was washed to remove unbound antibody and was then incubated with a 1:2000 dilution of a secondary antibody linked to anti-rabbit IgG-peroxidase for $30 \mathrm{~min}$. Next, the membrane was incubated for $5 \mathrm{~min}$ with $2 \mathrm{ml}$ Lumi-Light substrate solution, following which the solution was discarded. The membrane was placed on Saran Wrap, covered with another layer of Saran Wrap, and exposed to X-ray films for 1-10 min.

\section{Immunohistochemistry}

Immunohistochemical staining of $\mathrm{CH} 2, \mathrm{CH} 3, \mathrm{CL} 3, \mathrm{CL} 2$, and CL1 samples was performed by the Vectastain ABC kit (Vector Laboratories). The samples were fixed in $10 \%$ neutral buffered formalin at room temperature for $24 \mathrm{~h}$ and washed with PBS. Next, the fixed samples were rehydrated in graded ethanol (3 min each in 100\% $2 \times ; 95 \% 1 \times ; 70 \% 1 \times ; 50 \% 1 \times$ ) and embedded in paraffin. Paraffin-embedded tissues were sectioned into $8 \mu \mathrm{m}$ slices, which were then mounted onto poly L-lysine-coated slides. The slides were boiled in $10 \mathrm{mM}$ sodium citrate for $10 \mathrm{~min}$ and chilled on ice for $20 \mathrm{~min}$. They were then washed in $3 \%$ hydrogen peroxide for $10 \mathrm{~min}$ and blocked for $1 \mathrm{~h}$ at room temperature. The slides were incubated with the primary antibody followed by an anti-rabbit secondary antibody. Finally, the slides were immunostained using the $A B C$ detection kit and stained with DAB. Bovine and rat $\mathrm{CL}$ cells were cultured at up to $80-95 \%$ confluency on poly-D-lysinecoated chamber slides for $24 \mathrm{~h}$. The attached cells were washed with $1 \times \mathrm{PBS}$, fixed in $4 \%$ paraformaldehyde at room temperature for $20 \mathrm{~min}$, and dried at $37^{\circ} \mathrm{C}$ on a heat block for $5 \mathrm{~min}$. The slides were washed in $0.2 \%$ Triton X-100. They were incubated with the primary antibody (bovine 20 $\alpha$-HSD polyclonal antibody) and then an Alexa 488-conjugated antirabbit secondary antibody. Finally, the slides were counter stained with 4,6-diamidino-2-phenylindole and mounted. The slides were observed using a Nikon Eclipse TE-2000-E confocal microscope.

\section{Declaration of interest}

The authors declare that there is no conflict of interest that could be perceived as prejudicing the impartiality of the research reported.

\section{Funding}

This work was funded by a grant (code \#20080401034074) from the BioGreen 21 Program, Rural Development Administration, South Korea.

\section{Acknowledgements}

The authors thank Dr Y C Chang (Catholic University) and Dr H W Seong (Institute of Animal Science) for their helpful discussions and to Mrs Y S Kang for her technical assistance.

\section{References}

Akinola LA, Poutanen M, Vihko R \& Vihko P 1997 Expression of $17 \beta$ hydroxysteroid dehydrogenase type 1 and type 2, P450 aromatase and $20 \alpha$-hydroxysteroid dehydrogenase enzymes in immature, mature and pregnant rats. Endocrinology 138 2886-2892. (doi:10.1210/en.138.7. 2886)

Albarracin CT, Parmer TG, Duan WR, Nelson SE \& Gibori G 1994 Identification of a major prolactin-regulated protein as $20 \alpha$-hydroxysteroid dehydrogenase: coordinate regulation of its activity, protein content, and messenger ribonucleic acid expression. Endocrinology 134 2453-2460. (doi:10.1210/en.134.6.2453)

Arosh JA, Parent J, Chapdelaine P, Sirois J \& Fortier MA 2002 Expression of cyclooxygenases 1 and 2 and prostaglandin $E$ synthesis in bovine endometrial tissue during the estrus cycle. Biology of Reproduction 67 161-169. (doi:10.1095/biolreprod67.1.161)

Bradford MM 1976 A rapid and sensitive method for the quantitation of microgram quantities of protein utilizing the principle of protein-dye binding. Analytical Biochemistry 72 248-254. (doi:10.1016/00032697(76)90527-3)

Bryndova J, Klusonova P, Kucka M, Mazancova-Vagnerova K, Miksik I \& Pacha J 2006 Cloning and expression of chicken 20 $\alpha$-hydroxysteroid dehydrogenase. Journal of Molecular Endocrinology 37 453-462. (doi:10.1677/jme.1.02025)

Dufort I, Soucy P, Labrie F \& Luu-The V 1996 Molecular cloning of human type 3, 3a-hydroxysteroid dehydrogenase that differs from $20 \alpha$ hydroxysteroid dehydrogenase by seven amino acids. Biochemical and Biophysical Research Communications 228 474-479. (doi:10.1006/ bbrc.1996.1684)

Higaki Y, Kamiya T, Usami N, Shintani S, Shiraishi H, Ishikura S, Yamanoto I \& Hara A 2002 Molecular characterization of two monkey dihydrodiol dehydrogenases. Drug Metabolism and Pharmacokinetics 17 348-356. (doi:10.2133/dmpk.17.348)

Hirabayashi K, Ishida M, Suzuki M, Yamanouchi K \& Nishihara M 2004 Characterization and functional analysis of the $5^{\prime}$-flanking region of the mouse 20a-hydroxysteroid dehydrogenase gene. Biochemical Journal 382 975-980. (doi:10.1042/BJ20040276)

Ishida M, Chang K, Hirabayashi K, Nishihara M \& Takahashi M 1999 Cloning of mouse $20 \alpha$-hydroxysteroid dehydrogenase cDNA and its mRNA localization during pregnancy. Journal of Reproduction and Development 45 321-329. (doi:10.1262/jrd.45.321)

Jayasekara WS, Yonezawa T, Ishida M, Yamanouchi K \& Nishihara M 2004 Molecular cloning of goat 20 $\alpha$-hydroxysteroid dehydrogenase cDNA. Journal of Reproduction and Development 50 323-331. (doi:10.1262/ jrd.50.323)

Jayasekara WS, Yonezawa T, Ishida M, Yamanouchi K \& Nishihara M 2005 Expression and possible role of $20 \alpha$-hydroxysteroid dehydrogenase in the placenta of the goat. Journal of Reproduction and Development $\mathbf{5 1}$ 265-272. (doi:10.1262/jrd.16074)

Jez JM, Bennett MJ, Schlegel BP, Lewis M \& Penning TM 1997 Comparative anatomy of the aldoketo reductase superfamily. Biochemical Journal 326 625-636.

Lacy WR, Washenick KJ, Cook RG \& Dunbar BS 1993 Molecular cloning and expression of an abundant rabbit ovarian protein with $20 \alpha-$ hydroxysteroid dehydrogenase activity. Molecular Endocrinology 7 58-66. (doi:10.1210/me.7.1.58)

Liu H, Bellemare V, Labrie F \& Luu-The V 2007 Molecular characterization of the cynomolgus monkey Macaca fascicularis steroidogenic enzymes belonging to the aldo-keto reductase family. Journal of Biochemistry and Molecular Biology 104 75-80. (doi:10.1016/j.jsbmb.2006.10.004)

Madore E, Harvey N, Parent J, Chapdelaine P, Arosh JA \& Fortier MA 2003 An aldose reductase with $20 \alpha$-hydroxysteroid dehydrogenase activity is 
most likely the enzyme responsible for the production of prostaglandin $F_{2 \alpha}$ in the bovine endometrium. Journal of Biological Chemistry 278 11205-11212. (doi:10.1074/jbc.M208318200)

Mao J, Duan WR, Albarracin CT, Oarmer TG \& Gibori G 1994 Isolation and characterization of a rat luteal cDNA encoding $20 \alpha$-hydroxysteroid dehydrogenase. Biochemical and Biophysical Research Communications 201 1289-1295. (doi:10.1006/bbrc.1994.1844)

Min KS, Hiyama T, Seong HH, Hattori N, Tanaka S \& Shiota K 2004 Biological activities of tethered equine chorionic gonadotropin (eCG) and its deglycosylated mutants. Journal of Reproduction and Development 50 297-304. (doi:10.1262/jrd.50.297)

Miura R, Shiota K, Noda K, Yagi S, Ogawa T \& Takahashi M 1994 Molecular cloning of cDNA for rat ovarian 20 $\alpha$-hydroxysteroid dehydrogenase (HSD1). Biochemical Journal 15 561-567.

Nakajima T, Yasuda $K$, Nishizawa $M$, Okada $H$, Yoshimura T, Ito $S$ \& Kanzaki H 2003 Expression of 20 2 -hydroxysteroid dehydrogenase mRNA in human endometrium and deciduas. Endocrine Journal $\mathbf{5 0}$ 105-111. (doi:10.1507/endocrj.50.105)

Penning TM 1997 Molecular endocrinology of hydroxysteroid dehydrogenase. Endocrine Reviews 18 281-305. (doi:10.1210/er.18.3.281)

Seong HH, Min KS, Kang MH, Yoon JT, Jin HJ, Chung HJ, Chang WK, Yun SG \& Shiota K 2002 Change in ovarian and placental 20 $\alpha$-HSD activity during the pregnancy in the rat. Asian-Australasian Journal of Animal Sciences 16 342-347.

Schuler G, Teichmann U, Kowalewski MP, Hoffmann B, Madore E, Fortier MA \& Klisch K 2006 Expression of cyclooxygenase-II (COX-II) and 20 $\alpha$-hydroxysteroid dehydrogenase $(20 \alpha$-HSD)/prostaglandin F-synthase (PGFS) in bovine placentomes: implications for the initiation of parturition in cattle. Placenta 27 1022-1029. (doi:10.1016/j.placenta. 2005.11.001)
Shiota K, Seong HH, Noda K, Hattori N, Ikeda A, Ogura A, Itagaki S, Takahashi M \& Ogawa T 1993 20 $\alpha$-Hydroxysteroid dehydrogenase activity in rat placenta. Endocrine Journal 40 673-681. (doi:10.1507/ endocrj.40.673)

Stickler RC, Tobias B \& Covey DF 1981 Human placental 17ß-estradiol dehydrogenase and 20a-hydroxysteroid dehydrogenase. Journal of Biological Chemistry 256 316-321.

Stocco CO, Zhong L, Sugimoto Y, Ichikawa A, Lau LF \& Gibori G 2000 Prostaglandin $\mathrm{F}_{2 \alpha}$-induced expression of $20 \alpha$-hydroxysteroid dehydrogenase involves the transcription factor NUR77. Journal of Biological Chemistry 275 37202-37211. (doi:10.1074/jbc.M006016200)

Stocco CO, Lau LF \& Gibri G 2002 A calcium/calmodulin-dependent activation of ERK1/2 mediates JunD phosphorylation and induction of nur77 and $20 \alpha$-hsd genes by prostaglandin $\mathrm{F}_{2 \alpha}$ in ovarian cells. Journal of Biological Chemistry 277 3293-3302. (doi:10.1074/jbc.M110936200)

Warren JC, Murdock GL, Ma Y, Goodman SR \& Zimmer WE 1993 Molecular cloning of testicular 20 $\alpha$-hydroxysteroid dehydrogenase: identity with aldose reductase. Biochemistry 32 1401-1406. (doi:10. 1021/bi00057a003)

Zhang Y, Dufort I, Rheault P \& Luu-The V 2000 Characterization of a human 20 $\alpha$-HSD. Journal of Molecular Endocrinology 25 221-228. (doi:10.1677/jme.0.0250221)

Received 25 March 2011

First decision 18 April 2011

Revised manuscript received 6 September 2011

Accepted 9 September 2011 